\title{
Writing the Histories of Dada and Surrealist Exhibitions: Problems and Possibilities Kathryn M. Floyd
}

Temporary art exhibitions materialize and dematerialize within the narratives of Dada and surrealism's many pasts. The displays at the Galerie Dada in Zurich, Cologne's Dada-Vorfrühling event, the International Dada Fair in Berlin, and the Paris Exposition Internationale du Surréalisme, are but a few examples of significant exhibitionary moments enacted by these radical groups. The broader critical strategies the Dadas and surrealists harnessed through their self-produced events and environments, from performance and provocation to appropriation, assemblage, intervention, and immersive experience, also make up some of the richest themes explored by scholars of the "historical avant-garde." In this sense, the Dada and surrealists' approaches to the display of images and objects might simply be another version of their typical tactics. Their self-produced temporary arrangements are integral to their overall goals and practices and thus at first seem obvious in meaning. And yet, in the same way that Leah Dickerman once described the overall state of Dada scholarship as "paradoxically underwritten and overwritten" ("Dada Gambits" 4), the topic of the Dada or surrealist exhibition, despite its inherent relationships to the well-studied strategies of these (distinct but intermingled) groups, has remained surprisingly invisible as a circumscribed, focused framework of analysis. Have considerations of these movements' vanguard displays of art (and anti-art) simply been subsumed into more fruitful topics of discourse? What might it mean to view their histories through a narrowed focus on their engagements with exhibitionary forms and practices? Does the contemporary concept of exhibiting (as a consciously pursued medium or process) align with their histories? Are Dada and surrealist exhibitions truly connected to one another, in the same way that the two "movements" have often been understood as tethered? Or, are they altogether different practices and thus another argument for delinking one from the other? Why have the relationships between surrealism and its art exhibitions garnered more concentrated scholarly attention than those produced by the Dadas? Could, or should, there be a history of Dada and surrealist exhibitions?

This special issue of Dada/Surrealism offers a place to consider these and other questions. It is not intended as a definitive statement, but as a springboard for 
ongoing study of Dada and surrealism's critical display tactics and the wider history of the mediation, distribution, and reception of art in the modern era. The authors in this issue provide important contributions to the study of Dada and surrealism, but also to a growing field called "exhibition history and theory" or "exhibition studies" that locates itself primarily, but not exclusively, in the history, criticism, and theory of art and visual culture. The past twenty years have seen the development of this innovative scholarship that seeks to understand the ephemeral exhibition, gallery space, and other temporary displays, distinct from more "permanent" formats of private collections and museums, subjects long tackled by other fields. This special issue continues the conversation about eventbased displays of art, which were central to Dada and surrealist operations.

\section{A History of Exhibitions}

The study of temporary art exhibitions grew from late twentieth-century debates about the ways in which context and situation, including the mediation, spectatorship, and reception of works of art, are central to defining and understanding an object or image. The recent interest in exhibitions and other circuits through which images travel is linked back to modern shifts in thinking of meaning and status, especially aesthetic meaning, as constructed and relative, not ideal, essential, or fixed. This attitude is linked to methodologies like poststructuralist thought, semiotic theory, and materialist history, as well as to the social approaches to art history of scholars like Arnold Hauser and T. J. Clark and the institutional philosophies of art articulated by Arthur C. Danto and George Dickie. That these perspectives often identify Dada and surrealism (but especially Dada) as a key influence in their development, or make use of avant-garde cases to articulate their theories, must be borne in mind. In many ways, the original concerns and strategies of Dada and surrealism, and those derived from our analysis of their practices and histories, have directly and indirectly incubated a broader interest in ephemeral exhibitions.

While some of the earliest studies of art exhibitions began in the late 1960s with books like Georg Friedrich Koch's 1967 Die Kunstausstellung and Lawrence Alloway's 1968 study of the Venice Biennale, wider interest in the history of exhibitions and display practices took off in the 1970s and 80s in European and American history, museum studies, and art history, theory, and criticism. Scholars published on topics like the politics and phenomenology of space, spectacle and spectatorship, and other fundamental exhibitionary problems. Some derived from postmodern theory. Some were driven by commentary on minimalism and postminimalism's "theatrical" engagement with context, while others were associated with Institutional Critique's responses to the power of the museum. Scholars also analyzed authoritative, and often overtly nationalist and imperialist, nineteenthcentury displays such academy salons and world's fairs, as well as the modern "white cube" gallery, in whose seeming neutrality and "invisibility" Brian 
O'Doherty located an aestheticized capitalist ideology built on commodity fetishism. Forty years on, his seminal Inside the White Cube remains fundamental reading for historians of exhibitions.

This early scholarship began to articulate itself as a discrete field of study in the early 1990s when now-classic volumes like the anthology Thinking About Exhibitions (1994) and Mary Anne Staniszewski's The Power of Display: A History of Exhibition Installations at the Museum of Modern Art (1998) further codified key issues, themes, and methods. The great proliferation of new "biennials" in the 1990s and early 2000s, large periodically produced exhibitions that survey the state of contemporary art, also drove critical inquiry about the power of temporary exhibitions and their organizers to write art history, propel the art market, and create (or reject) various kinds of value. By the turn of the millennium, exhibition studies were becoming a legitimate and more widely practiced specialty. Journals such as On-Curating (2008), The Exhibitionist (2010), and the Journal of Curatorial Studies (2012), along with book series like Afterall's Exhibition Histories (2010), were launched. In their pages, and in those of a host of new books, articles, and conferences, a widening range of topics extended the subfield's geographical, chronological, and thematic perspectives.

Most recently, cohorts of emerging scholars, many of them with museum backgrounds or degrees from new graduate programs devoted to curating, have opened up the field to more nuanced perspectives by critiquing the field's earlier literature or working to illuminate blind spots. But, as the field becomes more professionalized, scholars have also shored up its priorities and parameters. For example, Lucy Steed's useful 2014 volume Exhibitions appeared in Whitechapel's "Documents of Contemporary Art" series, which anthologizes key sources and influential texts around fundamental themes in contemporary art. Similarly, the field has "curated," so to speak, a canon of historically important exhibitions. Paralleling the typical modernist genealogy of original styles and artworks in the twentieth-century, this canon celebrates exhibitions that embody groundbreaking concepts or possess innovative installations and striking contents. The conventional, expected, or traditional (which would describe the vast majority of exhibitions, including some historical Dada and surrealist examples) is nowhere to be found in books like Bruce Altshuler's two volume Exhibitions That Made Art History (2008 and 2013) or Jens Hoffmann's Showtime: The 50 Most Influential Exhibitions of Contemporary Art (2014). A handful of Dada and surrealist exhibitions count among this canon of landmark events, specifically, the1920 Berlin Dada Fair, the 1938 Paris International Exposition of Surrealism, and New York's 1942 First Papers of Surrealism. These exhibitions therefore are important historical cases not only in the study of Dada and surrealism, but in the field of exhibition studies as well. 


\section{Methods for the Madness}

The history of exhibitions also possesses a canon of established themes and approaches. While there is little agreement about whether exhibitions are media, form, practice, or process, "group shows," like the Dada and surrealist examples above, sit resoundingly at the center of it all. Originating in annual academic salons, the disparate contents of multi-artist shows are selected and assembled through the efforts of juries, exhibition organizers, or groups of self-exhibiting artists. Less determined by the narrow, impersonal logic of an individual career trajectory, as in artists' retrospectives or solo shows like the 1921 Paris exhibits for Max Ernst at Au Sans Pareil or Man Ray at Librarie Six, or by the market-driven assortment of desirable images displayed by a dealer, group shows instead create new links between objects. They employ unifying themes and contexts, the identification of significant commonalities, or the self-definition of artist groups with shared aesthetic principles, beliefs, or goals to create a new whole out of disparate parts. In this way, the organization of a group show, whether by artists themselves, as in the case of the iconic Dada and surrealist exhibitions, or amateur or professional exhibition organizers, has come to be understood as a constructive, "creative," or intellectual act, often on a par with art-making itself.

At their foundation, group shows embody the power of selection, the principle that now forms the core of contemporary notions of "curating" and "the curatorial." From its earlier associations with the caretaking and management of established collections and museums, it has come to describe the powerful activities of valuing, selecting, and arranging. As avant-garde artist groups began more and more to arrange their own displays and independently manage their work's dissemination, a new form of exhibition organizer (with increasing independence from established institutions) took on various types of aesthetic thinking, intellectual labor, and creative responsibility typically associated with artists. In his essay on "The Curatorial Turn," Paul O'Neill states, "[ $t$ ]he idea of the curator as some type of meta-artist became prominent in the nineties ..." (252), although he and others trace the origins of this shift to the avant-garde and to Duchamp (250-51). Duchamp's famous redefinition of art as choosing, not making ("Whether Mr. Mutt with his own hands made the fountain or not has no importance. He CHOSE $\mathrm{it}^{\prime \prime}$ ) is understood as part of the same trajectory that redefined the term "to curate" and transformed exhibition makers into artists. Despite the deeply collaborative processes, tensions between practical concerns and ideal aims, and complex forces at work in the making of all exhibitions, these events are nevertheless "authored" by the individual curator standing at the helm.

Because curating is likened to artistic practice - indeed it could be described as a kind of collage or assemblage process - it is no surprise that exhibition studies, so closely tied to art history, have focused, almost obsessively, on the lives and careers of important curators and the practices, concepts, and histories that define their work. Likewise, what curators produce, the unique exhibition, is also the 
field's preferred subject of focus, or, in this case, "object," of study. Curators and the analysis of their individual exhibitions are at the center of exhibition studies in the same way that artists and the interpretation of works of arts are the bread and butter of traditional art history. But the responsibility and creative intentionality ascribed to modern curating often obscures the more complicated processes that make up each exhibition, and the idea of an event as a bounded, knowable object veils an exhibition's spatial, temporal, social, economic, and ideological complexity. While it purports to be a visual display, much of what makes up an exhibition is in fact invisible.

But art history's approaches are embedded in visual analysis and the use of visual data, whether works of art, design, and architecture or archival documentation. And because scholars in the art world are most comfortable dealing with visual materials, and often prioritize visual evidence above all else, they typically bypass, overlook, or fail to analyze historical exhibitions that cannot in some way be "experienced" visually, that is, either visited first hand or vicariously through the examination of sketches and plans or the "empirical" data provided by photographic or filmic documentation. As Bruce Altshuler notes in the preface to volume 1 of Exhibitions That Made Art History, the existence of photographic documentation was (mostly) a "fundamental selection criterion" in compiling the twenty-four landmark exhibitions in his influential anthology (7). Certainly it is more difficult to study events for which little to no visual evidence exists, even when text-based descriptions and other types of archival material are available. In the case of any event, more (good) data is always better. And yet, as we can easily see in some of the well-known installation photographs from Dada and surrealist exhibitions, and as the Dadas themselves might attest, photographs are clearly rhetorical devices, not objective evidence. Their use value is limited and should not determine an event's historical worth. The famous installation photograph of the 1942 First Papers of Surrealism, in which Duchamp's Mile of String forms an " $\mathrm{X}$ " in front of the camera's lens, makes the point that visual documentation is not always a "way in" to these historical events. ${ }^{1}$

If we want a richer sense of the exhibitions that made up the activities of Dada and surrealism, we must be willing to look beyond the established canon of landmark exhibitions, to consider the many solo shows, modest gallery presentations, or other forms of display that might have been more conventional, less "shocking," or not as representative of what we consider Dada and surrealism's defining principles. The collaborative, spontaneous, chance-based, or anti-authoritarian tendencies of the Dadas can be put to use interrogating the contemporary notion of the curator. The spectacular, and often popular, exhibitions of the surrealists upset our received notions of exhibitions as "objects" and ask us to further consider the lines between exhibitions and installation art or

1 Reproductions of this famous photograph are widely available. See, for example, Altshuler, Exhibitions v. 1, 301 or Kachur 176. 
performance. It is important to note that many of the most interesting Dada or surrealist exhibitions, for example Max Ernst and Johannes Baargeld's collaborative and chance-based exhibitions in Cologne, are the stuff of myth but completely unknown to us visually. We must become comfortable with new kinds of evidence or innovative approaches that take us beyond the typical strategies of art history or museum conventions. In this and other ways, Dada and surrealism not only provide fertile ground for discovering new exhibition histories, but also for deepening, critiquing, or upsetting our approaches to the study of exhibitions and even the very notion of a "history of exhibitions" itself.

\section{Defining "Community" Outside and Inside the Museum}

The history of exhibitions not only studies the exhibitionary presentation of new works (as in the Dada's self-created shows in the teens and twenties), but also art historical exhibitions typically seen in museums, like Alfred Barr, Jr.'s famous 1936 survey of Dada and surrealism or the recent blockbuster Dada organized in Paris and Washington, D.C. Likewise, the history of exhibitions also evolved from and is related to the well-developed and closely related arena of museum and collection studies, whose examinations of both specific historical institutions and overarching museal concepts share obvious links. Dada, too, had its relationships with the museum. But usually these authoritative, traditional institutions were anathema to its core principles, especially its violent disdain for "high" culture's ossified values. The museum and its ordered (often historical) arrangements of masterpieces became one of many symbols of the powerful systems against which the Dadas railed in their merciless critiques of crippled bourgeois culture, stagnant traditions, and oppressive aesthetic hierarchies. "Dadaland," for example, first published in Paris in 1938 by Hans Arp, asserts the true and useful "fragility of life and human works" by describing the inevitable decay and destruction of "the pyramids, temples, cathedrals, the paintings of the masters," to be hurried along by the same Dada tactics that "gave the Venus de Milo an enema" (Arp 28). More to the point, in the earlier Der Kunstlump (1920) George Grosz excoriated Oskar Kokoschka for a wrongheaded "morality" that placed the protection of Old Master paintings in Dresden's Zwinger Picture Gallery above the lives of those involved in the violent street fighting raging outside the museum's walls (Doherty 73-74).

Despite the museum format's physical similarities to exhibitions and gallery displays, a recognition of the mausoleum-like stasis of the typical art history museum and its dangerously out of touch principles separated it from short-lived exhibitions that existed in the flux of the present, at least in the understanding of artists like Berlin's Dada dilettantes who, in the catalogue for their 1920 Dada Fair, "[acknowledged] as their sole program the obligation to make what is happening here and now - temporally as well as spatially - the content of their pictures" (Herzfelde 102). This durational divide between exhibitions and museums is still held up as a fundamental distinction between these formats (Greenberg et al. 2-3). 
Their contrasting qualities of (relative) permanence and ephemerality and stasis and kinesis in part may help to explain why the avant-garde often embraced the exhibition and gallery, despite certain correspondences of form and process with the museum whose values they often critiqued. Alongside the celebration of commodity culture, fashion, performance, intervention, photography, film, and the popular press, exhibitions of all sorts could likewise embody the rapidity and realities of the contemporary moment and its provocative modes of address or could provide logical sites for the critique of modern economies and marketplaces.

In addition to offering a temporality matched to their interests in the present over the past, the smaller scale and shorter time frame of the exhibition also provided opportunities for independence and spontaneity, not just in the production of images and objects, but also in their presentation and dissemination, in the same way that the Dadas' many self-published journals and anthologies allowed them to "curate" their own images and texts in flexible and responsive ways. Artists collaborated with each other, or with sympathetic dealers and gallery owners, to stage their work in displays that enhanced or extended their aesthetic goals rather than subsuming their advances within traditional gallery décor or unsuitable interior design. The futurists, suprematists, constructivists, and expressionists, all to varying degrees, made innovative choices for their selfproduced exhibitions: for example, decisions about venue, wall color, or the arrangement of images. These innovative exhibitions marked an avant-garde independence as well as a shared rejection of cultural stagnation.

As noted above, Bruce Altshuler, perhaps more than any other historian, has established the scholarship on these independently produced group exhibitions with his early important text The Avant-Garde in Exhibition: New Art in the Twentieth Century (1994). His study structures a standard progression of twentieth-century vanguard movements around key exhibitionary events, from the 1911 Blue Rider exhibition and 1916 Futurist 0-10 event to the 1951 Ninth Street Show and the groundbreaking 1969 When Attitudes Become Form. In this study, he links the history of a defining exhibition to a general survey of the group that produced it. The end result is a set of representative exhibitions, each presented as a kind of exemplary embodiment of a movement, that are as much springboards for a broad survey of the "historical avant-garde" as isolated studies of individual events. At the core of the book are chapters on the 1920 Dada Fair, the 1938 International Exposition of Surrealism in Paris, and New York's First Papers of Surrealism from 1942, which Altshuler employs to summarize Dada and surrealism. In all his examples, his narrative revolves around the central issue of community, both in terms of belonging and acceptance as well as rejection and exclusion, which these group shows represent. For Altshuler, this question of community is a crucial marker of the avant-garde. "The story of the avant-garde is that of mutual support among a community and reception of art by a public, all participants enmeshed in systems of personal and economic relations. ... Group exhibitions bring this social aspect to the fore" (8). In Altshuler's study, each exhibition becomes the object- 
based materialization of a circumscribed community of artists operating as a cohesive unit, even if only for a brief moment in time.

Leah Dickerman notes that in museum treatments of the histories of these same groups and movements (i.e. shows presenting the history of Dada or surrealism "after the fact"), an understanding of these communities as true discursive networks made up of both individuals with independent goals as well as groups with shared positions has been obscured or skewed in one direction or the other. ${ }^{2}$ The format of the museum exhibition, she writes, which has played a significant role in defining Dada's histories, overwhelmingly favors monographic approaches centered on key practitioners, solo shows, and retrospectives of Dada individuals (those same forms often ignored by exhibition histories), and therefore downplays the question of community that Altshuler and others find so significant and evident in the original group exhibitions ("Dada Gambits" 4-5).

When they have dealt with the Dadas as communities, museum exhibitions have indelibly underscored the definition of Dada as primarily proto-surrealist. In particular, Dickerman names the well-known MoMA exhibitions of 1936 and 1968 respectively, Alfred Barr's Fantastic Art, Dada, and Surrealism, and William Rubin's Dada, Surrealism, and Their Heritage, along with the 1978 Dada and Surrealism, Reviewed at London's Hayward Gallery, as particularly influential (4-5). Alfred Barr, famously interested in the progression of styles over time, a sense of history that he tried to institutionalize at MoMA through plans to continuously deaccession the old and acquire the new, located, like so many others, Dada's significance in its trail blazing for surrealism, a movement which, in some ways, had a much more overt life in exhibitions than its "predecessor."

It is a more complex notion of "community," a set of complicated and shifting relationships between individuals and groups, that is truly at the core of Dada and surrealism and is perhaps best embodied in their own self-generated avant-garde exhibitions. Although often obscured by the ways in which their histories have been written, for example the overarching geographical approach to defining Dada as a collection of urban hubs, these artists in fact freely shifted between and among centers, alliances, and activities, overlapping with individuals, geographies, and chronologies that would soon be known as surrealism. Tristan Tzara, Francis Picabia, Man Ray, and Marcel Duchamp in particular, moved in and out of different avant-garde groups and international locations, becoming some of the earliest twentieth-century "post-national" artists. Communities like New York held in common fundamental ideas and personal ties with European groups, but also with other American modernists, before they specifically, albeit briefly, chose the Dada moniker. Groups outside the main centers, those in places like Portugal, Romania, Russia, or Japan, had links to, influenced, and were influenced by, "mainstream" Dada and surrealism, but also maintained their own equally

2 Dickerman was also one of the organizers of the blockbuster Dada exhibition (2005-2006) and the editor of the show's impressive American catalogue. 
significant individual contributions in their own specific contexts, despite being continuously shunted to the margins by historians.

Rewriting Dada and surrealism's histories through a survey of both group exhibitions and their historical treatments in the museum can do more than simply reify the idea of a community into a series of landmark events, the approach taken by Altshuler's book on the avant-garde. Instead, an examination of a set of historical exhibitions across time allows us to see not only the ways individuals and objects came together, but also the ways artists maintained their independence, arrived, departed, and arrived again, or negotiated the everchanging cliques of artists, writers, performers, and thinkers that make up what we call "Dada" or "surrealism." We also become acutely aware of the power of history, especially as it is articulated in the museum, to shore up what become static categories, definitions, and associations, even as Dada and surrealism were still in operation. Because exhibitions pinpoint moments of short duration, they offer us, not eternal representations of unchanging "movements," but snapshots of dynamic sets of individuals and objects coalescing, disbanding, and coming together again around a set of very present concerns at a particular point in time. Exhibitions allow us to look deeply at a single moment, an important approach for dealing with artists for whom understanding and engaging "the present" was a primary concern. Within such a focused chronological frame, scholars are better able to see the rich political, social, economic, and aesthetic agents in play around Dada and surrealist exhibitions. The traditional geographic structures of Dada, in particular, which seem to assign each individual or artwork a permanent location (Berlin, Paris, New York, etc.), are also unsettled by an examination of exhibitions. In short, these events help us track the variable movement of artists and agents and their works diachronically across time and space while also allowing us more sustained synchronic access to their temporary stopping points along the way.

\section{Disrupted Disciplines and Alternative Approaches}

The museum has also primarily defined Dada and surrealism through its visual art. But the Dadas famously used their group exhibitions as arenas in which to play with the shifting boundaries between media and other discrete categories and definitions; their events often interrogated the lines between object and space, artist and audience, image and performance, and environment and event, polarities that must be simultaneously maintained but also deconstructed to allow for critique. Sometimes these conceptual boundaries dissolved to create things that approximated a "total environment," precursors of today's installation art. The 1920 International Dada Fair in Berlin, with its collision of texts and images, ultimately looked very nearly like a three-dimensional example of one of the many photomontages it presented. That same year the Dada Early Spring exhibition organized by Max Ernst and Johannes Baargeld mixed performance, visitor participation (or "relational aesthetics"), and a tableau of objects at the end of a 
passageway in Cologne's Brauhaus Winter. Paris's 1921 Salon Dada extended its somewhat conventional installation in the Galerie Montaigne above viewers' heads and onto the ceiling, breaking down the typical spatial divisions of the gallery space. And at the opposite end of the spectrum, the grottos and hidden displays of objects in Kurt Schwitter's Merzbau were subsumed into their environment, where they merged with the architectural framework to the point that they became invisible.

The Dada breakdown of categories and information seen in its historical exhibitions has also encouraged alternative expressions of its histories, often through the critical potential located in an exhibition's ability to embody complexity, collision, and paradox. The study of Dada and surrealist exhibitions has fostered more "creative" research on the topic, experiential and practice-based studies that involve analysis as well as "making." At approximately the same time that Altshuler was laying the groundwork for his exhibition-centered history of the avant-garde, the Berlinische Galerie presented Stationen der Moderne: Die bedeutenden Kunstausstellungrn des 20. Jahrhunderts in Deutschland at the Martin Gropius Bau, a groundbreaking Ausstellung über Ausstellungen that traced a history of vanguard exhibitions in Germany, from Dresden's Brücke Group to international Fluxus and other radical 1960s movements. This 1988 "exhibition of exhibitions" was premised on the desire to open up the study of art to include not only objects made by artists but the significant social forces at work in circulating and defining their practices and ideas. ${ }^{3}$ The catalogue of the exhibition offered detailed chapters on each thoroughly documented event, the various "milestones" along this national route of modern art, but also thematic essays investigating the issues and problems of their study and history, from understanding the complex factors that come together to create a single exhibition (Roters) to defining the problems of the relationship of objects in and to space (Grasskamp) and discerning the relationships of private and public in the reception of art on display (Merkert).

Stationen der Moderne also took up an interesting methodological solution for the study of exhibitions, that of the "remembering exhibition," as Reesa Greenberg terms it, an exhibition that studies the history of exhibitions through the very practice of exhibiting. (Greenberg, "Archival" 159) The organizers of Stationen der Moderne replicated, to varying degrees, some of the historical exhibitions under consideration. The accompanying catalogue, full of excellent scholarship, documentary information, and image reproductions, also offered, for example, a portfolio of facsimile editions of the original exhibition catalogues and brochures

3 It should also be noted that these interests in analyzing the power and significance of museums, exhibitions, galleries, and dealers in the 1980s and 90s coincides with an economic upturn in the art market, a surge in museum building and attendance, and a great proliferation of biennials and other temporary cultural events all of which reinvigorate local economies. 
from the shows in question. The exhibition went to great lengths to partially reproduce the main room of Berlin's 1920 Dada Fair, complete with original works of art such as Hannah Höch's Cut with the Kitchen Knife (1919), reproductions of unobtainable objects or lost images like George Grosz's Germany, A Winter's Tale (1918), relevant archival materials, and, of course, a recreation of the infamous "Prussian Archangel" hanging from the ceiling. This merging of archival materials with strategies of restaging could also be seen in Surrealism USA, a 2005 exhibition at New York's National Academy where organizers reinstalled Duchamp's Mile of String from First Papers of Surrealism alongside installation shots of the 1942 event. ${ }^{4}$

As a careful execution of pointed juxtapositions and meaningful spatial relationships that simultaneously expressed the energy, chaos, and complexity of the 1920 show, the new Dada Fair at the Martin Gropius Bau approximated the original hang but also went beyond mere reenactment. Each artwork on view, Greenberg writes, simultaneously "functioned as art and historic referent" ("Archival" 164). In this way, the recreation flattened the categories of "original" and "reproduction"; valuable artworks on loan from museums and collections were hung alongside color and black and white reproductions of paintings and montages printed specially for the Stationen der Moderne display. On the other hand, significant effort was made to include original period props to complete the scene. In a 2006 talk about the 1988 reconstruction, Helen Adkins, who played a key role in recreating the Dada Fair, stated that these collisions of categories (old and new, copy and original, artwork and archival document), which might seem spurious in other exhibition recreations, in fact emphasized and embodied (in essence, put "on display") Dada's most valued principles. The result, she noted, had a "sensual" rather than a "documentary" effect, that helped to reproduce some of the critical power of the original event. Exhibiting Dada, she concluded, "does open other possibilities of hanging and presentation" that other types of artwork or historical movements might not so readily allow. ${ }^{5}$ This affective research also holds great potential for understanding surrealism's installations, as some of the authors in this issue demonstrate.

Other exhibitions that tell Dada's and surrealism's histories have likewise been inspired by avant-garde principles and activities. The blockbuster 2005-2006 exhibition Dada, organized by Laurent Le Bon at the Georges Pompidou Center in Paris, for example, employed an unconventional dada-esque organization and effect to arrange the nearly 1000 objects on display in its massive survey of the movement. A chessboard layout of forty-five rooms, each dedicated to a different

4 For a brief description of Surrealism USA, at New York's National Academy (2005), go to: http://www.tfaoi.com/aa/5aa/5aa249.htm. Accessed April 2017.

5 Adkins's talk was given at the MoMA in 2006 as part of the final leg of the Pompidou's Dada exhibition. Audio of that talk can be accessed on the MoMA website: http://www.moma.org/explore/multimedia/audios/61/96. Accessed Aug. 2013. 
individual, Dada center, or concept, allowed visitors to create their own exhibitionary logic from the fragmented histories on view as they moved through the spaces, in opposition to standard chronological or geographical Sada narratives. The popular show then traveled to the National Gallery in Washington DC and the Museum of Modern Art in New York, where different curatorial solutions and new arrangements remade the flexible survey in ways appropriate to those venues.

\section{Monographic Achievements}

A large portion of Hanne Bergius's important study (published in 1989 in German and in 2003 in English translation) of Berlin Dada entitled Dada Triumphs!: Berlin 1917-1923 is a thorough reading the 1920 International Dada Fair. Her contribution is an important example of a sustained, sophisticated framing of a seminal avantgarde event. One of the only extended studies of a single Dada exhibition, Bergius not only examines the exhibition's spatial context, form, and content; she also delivers a highly detailed examination of the events leading up to the fair, as well as its reception and effects. She analyzes the politics behind the organization of the event, examines individual objects on view, and describes and interprets the design of the exhibition's installation. She also takes into account items often understood as tangential to the "real" exhibition: the show's publicity program, its catalogue, and its documentation in photographs and texts. Her study demonstrates that these "ephemera" are in fact inherent to the event itself. Most important, Bergius presents a reconstruction of the show, catalogues her archival findings, and includes primary texts and documentary photographs that give a complex picture of the exhibition and encourage further study.

To date, Bergius's scholarship remains the most concentrated analysis of a single Dada exhibition. With the exception of an unpublished Master's thesis (Grey, 2006), no one has tackled a diachronic survey of the history of Dada exhibitions in one or multiple Dada centers, or written a monographic analysis of the concept of curating or exhibiting in the movement. Surrealism's relationships with exhibitions, on the other hand, have fared far better, having received treatment in two book projects dedicated to surrealist events in France and the United States, from the canonical to the under-studied. The existence of these monographs, in particular Adam Jolles recent book on a diverse but interconnected selection of French surrealist exhibitions from 1925 to 1941, indicates the real integration of the study of these avant-garde events into Dada and surrealist studies, exhibition histories, but also "mainstream" art history.

Perhaps surrealist exhibition practices have received more scholarly treatment because the Paris group around André Breton was thoroughly engaged with exhibitions as an established format, and because the character of many of their seminal events make them easily consumable for the history of exhibitions. With the continuing adherence of Breton to more traditional notions of "high art" and 
its disciplinary divisions, the surrealists were more easily at home in "typical" aesthetic spaces like the elite art gallery. Their deep interest in objects and objecthood, along with their investigations of physical and psychological (and social and political) experiences, especially those in which the veil between the everyday and the unexpected was lifted, made exhibitions a ripe form through which to construct affective environments that might catalyze what Breton famously called a "revolution of the mind." Indeed, their seminal example of surreal beauty, Isidore Ducasse's "chance meeting of a sewing machine and an umbrella on a dissecting table," sounds like a description of so many surrealist installations and displays. Their best known events are some of the most thoroughly studied avant-garde exhibitions, no doubt due to their associations with popular artists like Duchamp and Dalí, their chronological proximity to early museum treatments of Dada and surrealism such as Barr's 1936 MoMA show, and their great influence on future artists and artworks. Most important, as Jolles makes clear, surrealism evolved during a time when there was an increasing consciousness about the power of independent exhibitions and a growing professionalization of curatorship as a circumscribed activity.

Many of surrealism's events fit naturally into the parameters and methodological frameworks of the study of historical exhibitions. They were often organized under clearly defined creative leadership who developed their unifying concepts or innovative exhibition designs through total environments. Most important, the surrealists, especially those in Paris and later New York, were selfconscious, intentional exhibition makers whose goals were not only the creation of affective, often spectacular environments but also the meaningful marketing of "surrealism" to broader audiences. And, in the wake of museum exhibitions like the 1936 MoMA survey, they already possessed a sense of themselves as important to (future) history, an understanding also found in the Dadas' self-historicizing through the production of anthologies. For this reason, surrealist events were often well catalogued and documented, and they created interesting exhibition ephemera (publicity materials, catalogues, invitations, posters, and other ancillary elements) that are useful to contemporary historians. These and other materials, in part, make possible the rich detail found in the two significant monographs on surrealist exhibitions.

A comparison of the goals and achievements of Lewis Kachur's Displaying the Marvelous: Marcel Duchamp, Salvador Dali, and Surrealist Exhibition Installations (2001) and Adam Jolles's The Curatorial Avant-garde: Surrealism and Exhibition Practice in France, 1925-1941 (2013) not only illustrates the potential for deep analysis of the history of Dada and surrealist exhibitions. Taken together, they also represent the way the study of these themes has been enhanced and expanded by the evolution of a field dedicated to looking broadly at the medium and process of exhibition making over time and space. Kachur's Displaying the Marvelous examines the exhibitions of late surrealism, a time when members had fully embraced exhibitionary formats, having had at least a decade to think through and 
experiment with the design and politics of various kinds of display. Kachur concentrates on two well-documented, canonical events, the 1938 Paris Exposition of Surrealism and New York's 1942 First Papers of Surrealism. He also includes a chapter on the complicated history behind Dalí's 1939 display for the New York World's Fair, which brought art exhibitions and installations into dialogue with the popular spaces of a world's fair. Kachur ends with another contrasting example, a discussion of Frederick Kiesler's surrealist gallery spaces at Peggy Guggenheim's Art of This Century as well as a final assertion of the importance of these histories for contemporary art from the 1940s to the 1990s. The through line in Displaying the Marvelous is not a strict, essentializing theory of exhibition making, but rather a concern for understanding the individual histories behind "ideological spaces" of display in which a "polemic [is] present in the format of the display itself" which no longer purports to be "neutral" (5-6). Kachur locates the beginning of the ideological exhibition space not with the surrealists whose exhibitions he examines, but rather around 1920 in a broad series of radial experiments by the Dadas and Russian constructivists, as well as in the spectacular displays of modern department stores.

Kachur's book is deeply descriptive in the best sense of the word. His comprehensive sketches of each event walk the reader not only through the space and contents of the different exhibitions, but through the planning, publicity, and aftermath of each event. As Kachur states at the outset, "my focus is more on case study than on theory" (xvi). Kachur also indicates that he understands his location at the forefront of exhibition studies where he is opening up new directions in the study of surrealism, and, like Bergius, setting up material for future analysis. In the preface he writes, "this book participates in a growing body of art historical investigation that has turned away from the more traditional monographic focus [on works of art and artists] to examine the dynamics of art world systems..." (xv). His book remains a significant contribution to both avant-garde studies and the history of exhibitions.

Kachur also notes that the surrealists, as well as critics and audiences of their era, "struggled for a vocabulary and framework to explicate these new environments" (9). In some ways Kachur, too, shares a similar problem in that he is marking out new scholarly territory. Adam Jolles, on the other hand, is the beneficiary of Kachur and others' trailblazing. The use of the term "curatorial" in his 2013 book's title is just one indication that a decade has passed between the publication of the two studies. An entirely new set of terms signifying complex exhibitionary concepts, in particular "the curatorial," is no longer provisional, but available and apparent to both Jolles and his readers. Like other recent authors, he is concerned with understanding the role of the curator in the specific context not simply of surrealist practice, but of a very particular place and time. As he writes, "this book focuses on ... the emergence of an amateur class of curators in France composed of writers and artists who actively sought to contribute to current curatorial discourse despite possessing no formal training in or substantial 
exposure to either museum or gallery work" (5). Jolles's examination of exhibitions produced by these novice "curators" from the early to later years of Paris surrealism, therefore, not only contributes to understanding this particular historical moment, but also to the understanding of the more general evolution of the curator. Once again, surrealism's exhibitions are shown to be fundamental not only to the movement, but to the overarching development of modern and contemporary exhibitionary practices.

Jolles's book also reflects its dual contributions in the fields of surrealist studies and exhibition histories through his engagement with lesser-known cases and theoretical approaches. Jolles moves away from self-produced group shows or "ideological exhibitions" with innovative designs and investigates a range of different events, almost all of them examined here for the first time. And while his selections are more diversified, his historical framework, 1925-1941 France, is more specific. His book begins with the very first surrealist group exhibition, the 1925 show at the Galerie Pierre in Paris, and then moves to analyze the Galerie surréaliste's 1928 retrospective of Giorgio de Chrico's early works, a single artist exhibition that, atypically, denounced de Chirico rather than celebrated him. Louis Aragon and Paul Eluard's 1931 exhibition The Truth About the Colonies, created as the surrealists grappled with their relationships with communism, was likewise unusual for its criticality and anti-imperialism. Jolles's approaches to these and other exhibitions move beyond deep description or empirical history, although they provide that too. While Kachur understandably declined to "theorize" the exhibitions in his earlier volume, Jolles's analysis engages myriad discourses from theories of the spectacular, psychoanalytic, and affective to concepts of agency, materialism, and objecthood, among others. At the center is a philosophy of "the curatorial" that for Jolles and other recent scholars of exhibitions is deeply entangled with the concepts and practices of art, but at the same time operates as a term whose complicated history and shifting meaning have settled into a legible shorthand for the power to create value and meaning through the relational processes of choosing, contextualizing, arranging, and presenting.

Jolles is also the author of the related essay "Artists into Curators: Dada and Surrealist Exhibition Practice," one of twenty-seven chapters in David Hopkins's 2016 A Companion to Dada and Surrealism. The book selects a set of themes deemed fundamental to understanding these important movements. Included here are essays on poetics, chance, insurrection, feminism, ethnography, nature, and desire. Jolles's contribution serves to establish the concentrated study of exhibitions as fundamental to a comprehensive understanding of Dada and surrealism. It is hoped that Jolles's book and essay, along with the work of past scholars and those of this issue, will help facilitate the future construction of a rich literature on the topic. 


\section{Exhibitions in Dada and Surrealism: New Scholarship}

The articles in this special issue of Dada/Surrealism demonstrate both the wide range of scholarly challenges to the study of these issues and the possibilities for future study. They approach a set of events, both well known and understudied, from a range of methods and strategies, from the analytical and descriptive to the critical and creative. Many of the essays draw from the typical approaches of the history of exhibitions, but just as often upset, disrupt, or question them. They each focus on specific exhibitionary cases and histories, but all make connections between them and other formats like art objects, journals, films, performances, novels, and collections. In short, these essays are important contributions to specific focused topics, but also catalysts for new inquiries and innovative approaches.

Katharina Hoins's essay "Johannes Baader's Postwar Plasto-Dio-Dada-Drama and German War Exhibitions During World War I" begins the issue not with the usual analysis of a Dada exhibition per se, but with an exploration of the ways exhibitions influenced Dada artworks and artistic practices. Hoins considers Baader's famous construction for the 1920 Dada Fair, the Plasto-Dio-Dada-Drama, as a response to German war memorial arrangements of trophies, weaponry, and military paraphernalia erected by the Prussian Ministry of War and the Red Cross. In her analysis, as in Baader's assemblage itself, newspaper fragments also figure prominently, thus engaging another key issue in the study of Dada exhibitions, the various relationships of images and texts (including the use of text and typography for signage, labeling, and catalogues) in and around exhibitions and displays. Emily Hage's essay "Mise-en-page to mise-en-scène: Intersecting Display Strategies in Dada Art Journals and Exhibitions" continues this theme by exploring the connections between printed periodicals and exhibition practices across Dada activities in Zurich, Paris, Cologne, and Berlin. Hage considers the arrangements of texts and images in the journals not as transportable, reproducible exhibitions alone. She also thinks through the format's twodimensional presentations of pictures and type as opportunities for the Dadas to work through potential curatorial choices that would later find their way into evocative three-dimensional installations.

Susan Rosenbaum likewise takes up the bonds between exhibitions and other modes of expression in her study of the ways avant-garde women responded to and re-imagined aesthetic presentations, not simply as spectators, but as curators, collectors, writers, and filmmakers. Rosenbaum interweaves the efforts of Katherine Dreier, Peggy Guggenheim, Mina Loy, and Maya Deren with Duchamp's objects and environments, which instigated a range of responses from these very different creators who subsequently formulated their own "spaces" of display (from the architectural to the filmic, literary, and conceptual) thereby activating a female gaze. In her untangling and reconnecting of various media and formats, Rosenbaum, like Hage, calls into question the isolation of exhibitions as a 
focus for studying the avant-garde, but also demonstrates the rich perspectives offered by an interdisciplinary examination of "display" as an evolving and unstable concept.

Unlike Rosenbaum's diachronic study that stretches from the teens into the 1940s and foregrounds the hazy divisions between the Dadas and other avantgarde groups across time and geography, articles by Adriana Ortega, Dafne Cruz Porchini, and Kerry Greaves produce close analyses of singular but little-studied events. These scholars also take up themes related to the interaction of exhibitions and other media and deal with the pivotal era of the 1940s, but they move us beyond the well-covered landscapes of Germany, France, and the United States. Ortega and Porchini's "The 1940 International Exhibition of Surrealism: A Cosmopolitan Art Dialogue in Mexico City" re-examines this landmark exhibition organized by Peruvian poet César Moro and Austrian artist Wolfgang Paalen which included work by Europeans as well as Mexican artists like Diego Rivera and Frida Kahlo. Ortega and Porchini look at the divisions and connections between the two groups as well as the confluences between performance and display and poetry and the visual arts that the event offered. Finally, the authors are also concerned to better understand the exhibition's layout and design, a challenge given the shortage of installation photographs and other archival evidence from the event.

Kerry Greaves grapples with a similar challenge in making sense of the Danish collective Helhesten's (The Hell-Horse) 1941 "Tent" exhibition, an underdocumented, experimental, short-lived installation in Copenhagen that collided art, social situations, and temporary outdoor architecture in a transgressive statement. Organized by a group of artists around Asger Jorn, the artist who would later help initiate the European Cobra movement of the late 40s and early 50s, the makeshift, carnivalesque event, which featured sculptures, paintings, periodicals, and ephemeral materials in a clearly provisional environment, reconceived the lessons of both German Dada and French surrealism for its Occupation-era Danish context.

The highly experimental, intensely transitory character of Helhesten's "Tent" is, with related questions of objecthood, juxtaposition, transdisciplinarity, and affect, an important element that makes early twentieth-century Dada and surrealist displays a continuing interest for both the rapid cycles of the contemporary art world and the criticality of many emerging artists. Wood Roberdeau's analysis of two very different contemporary presentations of the history of Kurt Schwitters in exile contrasts the Tate Britain's linear, historical exhibition of images and objects, Kurt Schwitters in Britain (2013), with the discursive, ephemeral, rhizomatic group activities (including a residency, performances, and exhibitions) of 27 Senses (2010, Kunstmuseet KUBE, Álesund and Chisenhale Gallery, London) which took up the topic of Schwitters's time in Norway. The latter project, produced by five artists working both together and apart, enacted and displayed new work grounded in the continuation of Schwitters's Merz processes (rather than his completed Merz 
"products") and in doing so avoided conventional art historical narratives, an anathema to the Dadas, as well as traditional divides between viewers and artists. As Roberdeau puts it, 27 Senses allowed the spectator "to learn through Schwitters rather than about him."

Carson \& Miller, a collaborative team of two artists/critics/scholars, like the individuals behind 27 Senses, also make exhibitions that bring Dada and surrealist tactics into the contemporary moment. Rather than create exhibitions that illustrate these histories, Carson \& Miller use avant-garde strategies to disrupt conventional exhibit presentations of the historical past. In "Playing in the Wunderkammer," they describe their 2009 installation The Story of Things, a hybrid art-making, curatorial, and critical undertaking. Their practice-based approach to understanding the avant-garde, a "de-arrangment" and de-narrativizing of the Manchester Metropolitan University Special Collections department, is not just a response to Dada and surrealism, but also an attempt to understand the power of contemporary museums, collections, and exhibitions in defining art history. Within these orderly realms they create freedom, play, and the unexpected. Carson \& Miller's work, their installation, catalogue, documentation, and even description and critical analysis of their own practice as it appears here in Dada/Surrealism, approximate the conventional elements of an exhibition, but ultimately frustrate expectations of coherence.

The inclusion of Carson \& Miller's work at the end of this special issue takes us back to basic questions about the divisions between message and medium, artwork and context, the diachronic and the synchronic, and the present and the historical past, in short, to the very foundations of defining the exhibition format, as well as key issues in Dada and surrealism. As a set, these essays both point to the potential offered by an exploration of a movement through the exhibitions produced by and about it, as well as the need for further study, not just of specific displays, but of the very ways we define, document, approach, and historicize the points at which artists, artworks, spaces, and spectators temporarily coalesce, before becoming the permanent, but never fully bounded, "objects" of memory and history.

\section{Works Cited}

Adkins, Helen. “The 1988 Reconstruction of Berlin's First International Dada Fair of 1920." Lecture, Museum of Modern Art New York, 2006. <http://www.moma.org/explore/multimedia/audios/61/96>. Aug. 2013. Web. Alloway, Lawrence. The Venice Biennale 1895-1968: From Salon to Goldfish Bowl. Greenwich: New York Graphic Society, 1968. Print.

Altshuler, Bruce. The Avant-garde in Exhibition: New Art in the 20 $0^{\text {th }}$ Century. Berkeley: U of California P, 1994. Print.

- Exhibitions that Made Art History. 2 vols. London: Phaidon, 2008-2013. Print. 
Bergius, Hanne. "Dada Triumphs!": Dada Berlin, 1917-1923. Trans. Brigitte Pichon. New Haven: GK Hall, 2003. Print. Crisis and the Arts 5.

Dickerman, Leah. Dada: Zurich, Berlin, Hannover, Cologne, New York, Paris. Washington: National Gallery of Art, 2005. Print.

—. "Dada Gambits." October 105 (Summer 2003): 4-12. Print.

Doherty, Brigid. "The Work of Art and the Problem of Politics in Berlin Dada." October 105 (Summer 2003): 73-92. Print.

Duchamp, Marcel. "The Richard Mutt Case." The Blind Man 2 (1917): 5. Print.

Greenberg, Reesa. "Archival Remembering Exhibitions." Journal of Curatorial Studies 1.2 (2012): 158-77. Print.

Greenberg, Reesa, Bruce W. Ferguson, and Sandy Nairne, eds. Thinking About Exhibitions. London: Routledge, 1996. Print. https://doi.org/10.1386/ jcs.1.2.159 1

Grey, Emily Rachel. Dada Exhibitions: A Survey and Analysis. M.A. Thesis. University of Maryland, 2006. 31 May 2017. Web.

Herzfelde, Wieland. "Introduction to the First International Dada Fair." Trans. and introd. Brigid Doherty. October 105 (Summer 2003): 93-104. Print.

Jolles, Adam. "Artists into Curators: Dada and Surrealist Exhibition Practices." A Companion to Dada and Surrealism. Ed. David Hopkins. Oxford: Wiley Blackwell, 2016. 211-24. Print. https://doi.org/10.1002/9781118476215.ch12

- The Curatorial Avant-garde: Surrealism and Exhibition Practice in France 1925-1941. University Park: Pennsylvania State UP, 2013. Print.

Kachur, Lewis. Displaying the Marvelous: Marcel Duchamp, Salvador Dali, and Surrealist Exhibition Installations. Cambridge: MIT P, 2001. Print.

Koch, Georg Friedrich. Die Kunstausstellung: Ihre Geschichte von den Anfängen bis zum Ausgang des 18. Jahrhunderts. Berlin: De Gruyter, 1967. Print.

O'Doherty, Brian. Inside the White Cube: The Ideology of the Gallery Space. Berkeley: U of California P, 1976. Print.

O'Neill, Paul. "The Curatorial Turn." The Biennial Reader. Ed. Elena Filipovic et al. Bergen: Bergen Kunsthalle; Ostfildern: Hatje Cantz, 2010. 240-59. Print.

Staniszewski, Mary Anne. The Power of Display: A History of Exhibition Installations at the Museum of Modern Art. Cambridge: MIT P, 1998. Print.

Stationen der Moderne: Die bedeutenden Kunstausstellungen des 20. Jahrhunderts in Deutschland. Berlin: Berlinische Galerie, 1988. Print.

Steeds, Lucy, ed. Exhibition: Documents of Contemporary Art. Cambridge: MIT P, 2014. Print. 